\title{
Pengembangan Media Pembelajaran Berbassis E-Learning Mata Kuliah Sistem Informasi Manajemen untuk Mahasiswa Akademi Komunitas Negeri Kabupaten Madiun
}

\author{
Vinanda U'un Ayuningtyas ${ }^{1}$, Munoto $^{2}$, Meini Sondang Sumbawati ${ }^{3}$ \\ ${ }^{1}$ Universitas PGRI Madiun \\ ${ }^{2,3}$ Universitas Negeri Surabaya
}

vinanda@unipma.ac.id

\begin{abstract}
Abstrak. Penelitian ini bertujuan untuk: 1) membuat e-learning yang memenuhi syarat layak atau valid sebagai media pembelajaran pada mata kuliah sistem informasi manajemen di Akademi Komunitas Negeri Kabupaten Madiun, 2) mengetahui hasil belajar mahasiswa yang lebih baik antara yang menggunakan media pembelajaran e-learning dengan yang menggunakan media pembelajaran powerpoint pada mata kuliah sistem informasi manajemen di Akademi Komunitas Negeri Kabupaten Madiun, 3) mengetahui respon mahasiswa terhadap media pembelajaran e-learning pada mata kuliah sistem informasi manajemen, 4) mendeskripsikan keterlaksanaan media pembelajaran e-learning yang dikembangkan di Akademi Komunitas Negeri Kabupaten Madiun. Jenis penelitian yang digunakan dalam penelitian ini adalah penelitian pengembangan dengan menggunakan model 4-D. Untuk ujicoba produk menggunakan intact group comparison yaitu membandingkan dua kelompok terdiri dari pembelajaran menggunakan media e-learning dan media powerpoint. Kedua kelompok diberi posttest pada akhir proses pembelajaran. Dalam penelitian ini diperoleh data hasil validasi media e-learning untuk aspek isi dikategorikan sangat valid dengan rata-rata hasil rating $85 \%$, aspek tampilan dikategorikan sangat valid dengan rata-rata hasil rating $84 \%$ dan aspek bahasa dikategorikan valid dengan rata-rata hasil rating 79,3\%. Sedangkan untuk tes hasil belajar diperoleh nilai rata-rata 85,5 untuk kelas eksperimen dan 79,5 untuk kelas kontrol. Hasil belajar mahasiswa dari kedua kelompok tersebut kemudian dibandingkan menggunakan uji t. Dari hasil uji $t$ diperoleh dari $t_{\text {hitung }}$ sebesar 3,747 sedangkan nilai $t_{\text {tabel }}$ dengan membandingkan kedua nilai $t_{\text {hitung }}$ dan $t_{\text {tabel }}$ diketahui bahwa $t_{\text {hitung }}>t_{\text {tabel. }}$ Mengacu pada nilai $t_{\text {hitung }}$ dan $t_{\text {tabel }}$ maka pengambilan keputusan hipotesis adalah terima $\mathrm{H}_{1}$ yaitu hasil belajar mahasiswa yang menggunakan media e-learning lebih tinggi daripada hasil belajar mahasiswa yang menggunakan media powerpoint. Hasil respon mahasiswa terhadap media $e$ learning rata-rata 3,396 dan dikategorikan sangat baik maka media e-learning layak digunakan dalam proses pembelajaran
\end{abstract}

\section{Kata Kunci:}

\section{Pendahuluan}

Pendidikan merupakan faktor kunci dalam meningkatkan kualitas sumber daya manusia. Pendidikan mempunyai peranan penting dalam hal ini. Oleh karena itu pendidikan perlu terus maju kualitasnya. 
Peningkatan tersebut dapat dilakukan melalui kurikulum, materi, pendidik, metode pembelajaran, dan juga media yang digunakan dalam pembelajaran.

Dalam pendidikan terdapat proses belajar mengajar, yang pada hakikatnya adalah proses penyampaian pesan atau informasi dari pendidik kepada peserta didik. Pesan atau informasi akan sampai kepada peserta didik apabila peserta didik dapat menangkap dan memahami isi pesan tersebut. Dengan penggunaan media yang tepat dalam proses belajar mengajar terjadi komunikasi yang lancar dan akan tercapai hasil yang maksimal. Salah satu penggunaan media pembelajaran adalah dengan memanfaatkan teknologi internet. Dalam Arsyad (2011:15) mengemukakan bahwa pemakaian media pembelajaran dalam proses belajar mengajar dapat membangkitkan motivasi, rangsangan kegiatan belajar dan dapat mencapai tujuan pembelajaran.

Sejalan dengan perkembangan teknologi yang demikian pesat, terutama teknologi komunikasi telah membawa perubahan besar dalam berbagai bidang. Salah satu bidang yang juga berkembang sebagai akibat kemajuan teknologi komunikasi ini adalah bidang pendidikan dan pembelajaran. Jika waktuwaktu sebelumnya hubungan antara pendidik - peserta didik hanya dapat berlangsung melalui kegiatan tatap muka, dibatasi oleh sekat ruang dan waktu, atau melalui media cetak, ternyata saat ini telah dikembangkan melalui media komunikasi online yang menembus sekat-sekat ruang dan waktu. Media komunikasi elektronik secara online disebut juga e-learning (Aunurrahman, 2011:120).

Mata kuliah sistem informasi manajemen di Akademi Komunitas Negeri Kabupaten Madiun Jurusan Teknik Informatika pada semester genap mempunyai bobot 3 SKS, ruang lingkup mata kuliah tersebut memuat tentang konsep sistem informasi dan membangun sistem informasi. Demi pencapaian proses belajar mengajar pada mata kuliah ini maka diperlukan media pembelajaran yang menarik, dapat download materi ajar, dapat menyajikan video membangun sistem informasi, dapat saling berdiskusi/forum dengan pengajar di manapun/kapanpun. Maka sistem informasi manajemen ini cocok dengan menggunakan media pembelajaran e-learning.

Berdasarkan hasil dari wawancara dengan dosen dan mahasiswa di Akademi Komunitas Negeri di Kabupaten Madiun khususnya Jurusan Teknik Informatika sampai saat ini media pembelajaran yang digunakan adalah media pembelajaran powerpoint, pembelajaran yang digunakan berlangsung satu arah berpusat pada dosen dan sumber informasi dari dosen saja, tersedia fasilitas internet dengan bandwith $8 \mathrm{mbps}$, laboratorium komputer yang terhubung dengan internet, tetapi belum dimanfaatkan secara maksimal dalam pembelajaran dan belum ada komunikasi timbal balik yang dilakukan dosen dan mahasiswa melalui online atau internet (catatan peneliti, 2015). Maka atas latar belakang ini penulis melakukan penelitian pengembangan media pembelajaran berbasis e-learning pada mata kuliah sistem informasi manajemen.

\section{Teori}

Azhar (2011:24-25) mengemukakan manfaat media pembelajaran dalam proses belajar mahasiswa, yaitu: a) Pembelajaran akan lebih menarik perhatian mahasiswa sehingga dapat menumbuhkan motivasi belajar, b) Bahan pembelajaran akan lebih jelas maknanya sehingga dapat lebih dipahami oleh mahasiswa dan memungkinnya menguasai dan mencapai tujuan pembelajaran, c) Metode mengajar akan lebih bervariasi, tidak semata-mata komunikasi verbal melalui penuturan kata-kata oleh pengajar, sehingga mahasiswa tidak bosan dan dosen tidak kehabisan tenaga, apalagi kalau pengajar mengajar pada setiap jam kuliah, d) Mahasiswa dapat lebih banyak melakukan kegiatan belajar sebab tidak hanya mendengarkan uraian pengajar, tetapi juga aktivitas lain seperti mengamati, melakukan, mendemonstrasikan, memerankan, dan lain-lain.

E-learning pada dasarnya adalah komputer dan jaringan memungkinkan transfer keahlian dan pengetahuan. E-learning mengacu menggunakan aplikasi elektronik dan proses belajar. E-learning konten disampaikan melalui internet, intranet/extranet, audio atau video tape, TV satelit, dan CDROM (Nagarajan, 2010:38). Adapun kelebihan dan kekurangan pembelajaran berbasis e-learning, kelebihan diantaranya adalah: (1) Akses tersedia kapanpun,dimanapun (2) materi pembelajaran bisa diperbarui secara lebih mudah (3) rancangan pembelajaran berbasis e-learning memungkinkan dilakukannya kegiatan pembelajaran yang sudah terpersonalisasi. 
Menurut Amiroh (2013:1-3) moodle merupakan program open source yang paling terkenal di antara program-program e-learning yang ada. Kelebihan LMS Moodle berbeda dengan yang lain: a) sederhana, efisisen dan ringan serta kompatibel dengan banyak browser, b) instalasi yang sangat mudah, c) dukungan berbagai bahasa termasuk Bahasa Indonesia, d) Tersedianya manajemen situs untuk melakukan pengaturan situs secara keseluruhan, perubahan modul, e) Tersedianya manajemen pengguna, f) Tersedianya manajemen course yang baik, g) Tersedianya modul chats, modul polling, modul forum untuk jurnal, modul untuk kuis, modul untuk workshop dan survey.

Validitas berasal dari kata validity yang mempunyai arti konsistensi penilaian antar validator menunjukkan tingkat kevalidan dan mengetahui kualitas terhadap media pembelajaran e-learning. Suatu skala atau instrumen pengukur dapat dikatakan mempunyai validitas yang tinggi apabila instrumen tersebut menjalankan fungsi ukurnya, atau memberikan hasill ukur yang sesuai dengan maksud dilakukannya pengukuran. Sedangkan tes yang memiliki validitas rendah akan menghasilkan data yang tidak relevan dengan tujuan pengukuran (Azwar, 1986:8).

Keterlaksanaan pembelajaran dapat dilihat dari persentase keterlaksanaan yang dinyatakan dengan kriteria terlaksana atau tidak terlaksana. Keterlaksanaan pembelajaran tersebut juga dinilai untuk mengetahui apakah pelaksanaan pembelajaran tersebut termasuk kategori sangat baik, baik, kurang baik atau tidak baik. Keterlaksanaan pembelajaran erat kaitannya dengan kegiatan mahasiswa dengan sumber informasi (media pembelajaran) untuk meningkatkan kompetensi-kompetensi tertentu yang akan ditingkatkan pada mahasiswa. Mahasiswa akan dapat dengan mudah menerima informasi/ilmu jika ditunjang dengan media pembelajaran yang memadai. Jadi mahasiswa langsung bisa menangkap informasi yang disampaikan dengan jelas dan utuh

\section{Metode Penelitian}

Jenis penelitian ini merupakan penelitian pengembangan menggunakan model 4-D. Dalam penelitian ini akan dikembangkan media pembelajaran berbasis e-learning pada mata kuliah sistem informasi manajemen. Penelitian pengembangan ini disebut model 4-D karena proses pengembangannya dibagi menjadi 4 tahapan, yaitu define, design, develop dan disseminate atau pendefinisian, perancangan, pengembangan dan penyebaran. Subjek dalam penelitian ini adalah mahasiswa D2 TI A dan D2 TI B dilakukan pada semester 2 (dua) Jurusan Teknik Informatika di Akademi Komunitas Negeri Kabupaten Madiun dilaksanakan pada semester genap.

Rancangan uji coba produk menggunakan Intact Group Comparison. Model uji coba ini dilakukan dengan membandingkan antara kelas kontrol dan kelas eksperimen. Pada kelas eksperimen mahasiswa diberi treatment atau perlakuan. Perlakuan yang dimaksudkan adalah dengan diberi media pembelajaran berbasis e-learning, sedangkan untuk kelas kontrol tidak menggunakan media $e$ learning tetapi menggunakan media powerpoint. Untuk mengukur perbedaan hasil belajar kelas kontrol dan kelas eksperimen didasarkan pada hasil posttest yang diberikan pada akhir pembelajaran. Desain uji coba produk tersebut adalah sebagai berikut:

$\begin{array}{lll}\mathrm{E}: & \mathrm{X} & \mathrm{O}_{1} \\ \mathrm{~K}: & & \mathrm{O}_{2}\end{array}$

Keterangan:

$\mathrm{X}$ : treatment atau perlakuan dengan diberi media e-learning

$\mathrm{O}_{1}$ : posttest kelompok eksperimen

$\mathrm{O}_{2}$ : posttest kelompok kontrol

(Sugiyono, 2010: 75)

Analisis ini digunakan untuk menganalisis hasil penilaian yang diberikan oleh dosen ahli dan dosen mata kuliah. Analisis ini juga digunakan untuk menganalisis respon mahasiswa terhadap penggunaan media pembelajaran berbasis e-learning. Analisis ini dilakukan untuk menialai kelayakan media dan butir soal posttest Telaah terhadap media pembelajaran berbasis e-learning yang dikembangkan 
meliputi aspek isi, tampilan dan bahasa. Sedangkan telaah untuk butir soal posttest meliputi aspek materi, konstruksi dan bahasa.

Bobot penilaian kualitatif untuk telaah media dan butir soal dapat dilihat pada Table 1.1.

Tabel 1.1 Bobot Penilaian Kualitatif
\begin{tabular}{|l|l|}
\hline Penilaian Kualitatif & Bobot \\
& Nilai \\
\hline Sangat valid & 5 \\
Valid & 4 \\
Cukup valid & 3 \\
Tidak valid & 2 \\
Sangat tidak valid & 1 \\
\hline
\end{tabular}

(Riduwan, 2011: 87)

Rumus yang digunakan untuk menghitung jumlah jawaban validator menggunakan rumus hasil rating sebagai berikut:

$$
H R=\frac{\sum_{1}^{5} n x i}{n x i \max } \times 100 \%
$$

Keterangan:

$\mathrm{n}=$ jumlah validator yang memilih nilai $i$

$i=$ bobot nilai penilaian kualitatif (1-5)

Selanjutnya hasil validasi dari dosen ahli dan dosen mata kuliah digunakan untuk mengetahui kelayakan media dan butir soal posttest. Hasil validasi tersebut selanjutnya dikategorikan sesuai dengan interpretasi skor kelayakan sebagai berikut:

Tabel 1.2 Interpretasi Skor Hasil Rating

\begin{tabular}{|l|l|}
\hline Penilaian & $\begin{array}{l}\text { Hasil } \\
\text { Rating (\%) }\end{array}$ \\
\hline Sangat Valid & $81-100$ \\
Valid & $61-80$ \\
Cukup Valid & $41-60$ \\
Tidak Valid & $21-40$ \\
Sangat tidak Valid & $0-20$ \\
\hline
\end{tabular}

(Riduwan, 2011: 89)

\section{Statistik uji t}

Untuk mengetahui perbedaan hasil belajar siswa antara kelas kontrol dan kelas eksperimen, dilakukan dengan menggunakan uji-t. Uji-t digunakan untuk membandingkan antara dua keadaan yang berbeda. Didalam penelitian ini peneliti akan membandingan nilai hasil belajar posttest mahasiswa kelas eksperimen dan kelas control untuk mengetahui hasil belajar mahasiswa. Statistik yang di gunakan adalah dengan Uji-t satu pihak (pihak kanan).

\section{Melakukan uji prasyarat}

Uji prasyarat dilakukan untuk melihat normalitas dan homogenitas data. Uji ini dilakukan dengan merujuk pada hasil nilai posttest pengerjaan soal tes hasil belajar. Data yang memenuhi syarat haruslah data yang berdistribusi normal dan homogen. Data yang berdistribusi normal menunjukkan bahwa kecenderungan nilai data ada pada nilai rata-rata, bukan pada daerah ekstrim rendah maupun 
tinggi. Adapun data yang homogen menunjukkan bahwa sampel yang diambil dari populasi memiliki varian yang sama.

\section{Uji Normalitas}

Uji normalitas ini digunakan untuk menguji apakah sampel yang digunakan adalah sampel yang berdistribusi normal atau tidak. Uji statistik untuk uji normalitas data menggunakan teknik kolmogorov smirnov dengan bantuan software SPSS versi 17.0.

\section{Uji Homogenitas}

Uji homogenitas dilakukan dengan melakukan uji $\mathrm{F}$ dengan menggunakan rumus:

$$
F_{\text {hitung }}=\frac{\text { var iansterbesar }}{\text { var iansterkecil }}
$$

(Sudjana, 2005: 250)

Kriteria pengujian:

Tolak Ho jika Fhitung > Ftabel terima Ho jika Fhitung < Ftabel

Dimana:

Ho $=$ Sampel homogen

H1 = Sampel tidak homogeny

Melakukan uji-t dengan menentukan hipotesis

$\mathrm{H}_{0}$ : hasil belajar mahasiswa yang menggunakan media e-learning lebih rendah hasil belajar siswa yang tidak menggunakan media pembelajaran berbasis $e$-learning

$\mathrm{H}_{1}$ : hasil belajar mahasiswa yang menggunakan media pembelajaran berbasis $e$-learning lebih tinggi daripada hasil belajar mahasiswa yang tidak menggunakan media pembelajaran berbasis e-learning.

Menghitung $\mathrm{t}$ dengan rumus:

(Sudjana, 2005: 239)

$$
t=\frac{\bar{x}_{1}-\bar{x}_{2}}{s \sqrt{\frac{1}{n_{1}}+\frac{1}{n_{2}}}}
$$

Dimana:

$\mathrm{t}=$ besarnya uji-t yang dihitung

$\mathrm{x} 1=$ rata-rata nilai kelas eksperimen

$\mathrm{x} 2 \quad=$ rata-rata nilai kelas kontrol

$\mathrm{n} 1=$ jumlah mahasiswa kelas eksperimen

n2 = jumlah mahasiswa kelas kontrol

$\mathrm{s} \quad=$ simpangan baku gabungan

Menghitung simpangan baku gabungan dari rumus:

$$
s^{2}=\frac{\left(n_{1}-1\right) s_{1}^{2}+\left(n_{2}-1\right) s_{2}^{2}}{n_{1}+n_{2}-2}
$$

Keterangan:

n1 : jumlah mahasiswa kelompok eksperimen

n2 : jumlah mahasiswa kelompok kontrol

s2 : simpangan baku 


$$
\begin{array}{ll}
s_{1}^{2} & \text { : varians kelompok eksperimen } \\
s_{2}^{2} & \text { : varians kelompok kontrol }
\end{array}
$$

Menarik kesimpulan

Terima $\mathrm{H}_{1}$ jika $\mathrm{t}_{\text {hitung }}>\mathrm{t}_{\text {tabel }}$

\section{Hasil Penelitian}

\section{Hasil Validasi Media Pembelajaran berbasis E-learning}

Validasi media pembelajaran dilakukan oleh 4 orang ahli yang terdiri dari 3 orang Dosen Universitas Negeri Surabaya dan 1 orang dosen Akademi Komunitas Negeri Kabupaten Madiun. Validator media terdiri dari ahli materi, ahli media pembelajaran dan ahli bahasa. Tujuan validasi ini agar media pembelajaran yang dibuat layak digunakan untuk penelitian.

Validasi media pembelajaran yang dikembangkan oleh peneliti pada mata kuliah sistem informasi manajemen. validitas media mendapat skor rata-rata $85 \%$, kesesuaian media mendapat skor rata-rata $84 \%$, dan kemenarikan media mendapat skor rata-rata $79,3 \%$. Sehingga dari hasil ini media pembelajaran e-learning layak untuk digunakan sebagai media pembelajaran.

\section{Hasil Respon Mahasiswa}

Respon mahasiswa terhadap penggunaan media e-learning sesuai dengan pertanyaan antara lain; 1) e-learning menjadikan kegiatan pembelajaran lebih menyenangkan dikategorikan sangat baik dengan skor rata-rata 3,56,2) e-learning meningkatkan keaktifan mahasiswa dikategorikan baik dengan skor rata-rata 3,16, 3) e-learning meningkatkan minat mahasiswa dengan skor rata-rata 3,24,4) e-learning hal yang baru dan sangat menarik dikategorikan sangat baik dengan skor rata-rata 3,40,5) e-learning membuat mahasiswa mudah memahami konsep yang komplek dan abstrak dikategorikan sangat baik dengan skor rata-rata 3,52,6) e-learning membuat mahasiswa lebih mudah menyelesaikan soal-soal dikategorikan sangat baik dengan skor rata-rata 3,40,7) e-learning meningkatkan daya serap atau retensi belajar dikategorikan sangat baik dengan skor rata-rata 3,36,8) e-learning cocok digunakan di Universitas dikategorikan sangat baik dengan skor rata-rata 3,48,9) e-learning cocok digunakan materi sistem informasi manajemen dikategorikan sangat baik dengan skor rata-rata $3,44,10) e$ learning sesuai dengan kurikulum yang digunakan di Universitas dikategorikan sangat baik dengan skor rata-rata 3,40 .

\section{Hasil Keterlaksanaan Media Pembelajaran}

Keterlaksanaan pembelajaran dengan menggunakan media pembelajaran e-learning dengan skor rata-rata 4 yang dikategorikan baik sehingga media pembelajaran e-learning dalam kegiatan belajar mengajar dapat terlaksana dengan baik. Keterlaksanaan pembelajaran erat kaitannya dengan kegiatan mahasiswa dengan sumber informasi (media pembelajaran) untuk meningkatkan kompetensikompetensi tertentu yang akan ditingkatkan pada mahasiswa. Mahasiswa akan dapat dengan mudah menerima informasi/ilmu jika ditunjang dengan media pembelajaran yang memadai. Jadi mahasiswa langsung bisa menangkap informasi yang disampaikan dengan jelas dan utuh.

\section{Hasil Belajar Mahasiswa}

Hasil belajar mahasiswa dengan menggunakan media e-learning mendapat nilai rata-rata hasil tes belajar untuk kelas eksperimen adalah $85,5 \%$ dan untuk kelas kontrol adalah 79,46\%. Berdasarkan hasil uji t pada Tabel 4.12 diketahui bahwa hasil thitung sebesar 3,747 sedangkan nilai tabel adalah 1,671. Mengacu pada hasil uji t maka diketahui maka $t_{\text {hitung }}>t_{\text {tabel }}$. Berdasarkan pada kriteria pengambilan keputusan hipotesis maka terima $\mathrm{H}_{1}$ yaitu hasil belajar mahasiswa yang menggunakan media $e$ learning lebih tinggi daripada hasil belajar mahasiswa yang menggunakan media powerpoint. 


\section{Hasil Penilaian Tes Tulis}

Kelas Eksperimen

Tabel 1.3 Nilai Posttest Kelas Eksperimen

\begin{tabular}{|c|c|}
\hline Kelas Interval & Frekuensi \\
\hline $75-77$ & 1 \\
\hline $78-80$ & 2 \\
\hline $81-83$ & 4 \\
\hline $84-86$ & 5 \\
\hline $87-89$ & 9 \\
\hline $90-92$ & 1 \\
\hline $93-95$ & 2 \\
\hline $96-98$ & 1 \\
\hline Jumlah & 25 \\
\hline
\end{tabular}

Kelas Kontrol

Tabel 1.4 Nilai Posttest Kelas Kontrol

\begin{tabular}{|c|c|}
\hline Kelas Interval & ekuensi \\
\hline $64-67$ & 1 \\
\hline $68-71$ & 1 \\
\hline $72-75$ & 3 \\
\hline $76-79$ & 6 \\
\hline $80-83$ & 7 \\
\hline $84-87$ & 4 \\
\hline $88-91$ & 2 \\
\hline $92-95$ & 1 \\
\hline Jumlah & 25 \\
\hline
\end{tabular}

\section{Uji Prasyarat}

\section{Uji Normalitas}

Data nilai posttest untuk kelas eksperimen dan kelas kontrol berdistribusi normal. data hasil belajar dikatakan terdistribusi normal apabila nilai signifikansi yang diperoleh dari pengujian normalitas $>0,05$. Data kelas eksperimen dan kelas kontrol berturut-turut memiliki nilai signifikansi 0,60 dan 0,92 . Karena kedua kelompok memiliki nilai signifikansi $>0,05$ maka dapat disimpulkan bahwa semua data hasil belajar pada masing-masing kelompok pengujian berdistribusi normal.

\section{Uji Hipotesis}

Uji hipotesis menggunakan uji t untuk mengetahui perbedaan hasil belajar mahasiswa antara kelas eksperimen yang menggunakan media e-learning dan kelas kontrol yang menggunakan media powerpoint. perolehan hasil $t_{\text {hitung }}$ sebesar 3,747 . Sedangkan nilai $t_{\text {tabel }}$ untuk $\mathrm{df}=48$ dan signifikansi 0,05 adalah 1,671. Dengan membandingkan kedua nilai $t_{\text {hitung }}$ dan $t_{\text {tabel }}$ diketahui bahwa $t_{\text {hitung }}>t_{\text {tabel }}$. Berdasarkan kriteria pengambilan keputusan hipotesis yaitu:

Tolak $\mathrm{H}_{0}$ : $\mathrm{t}_{\text {hitung }} \leq \mathrm{t}_{\text {tabel }}$

Terima $\mathrm{H}_{1}$ : $\mathrm{t}_{\text {hitung }}>\mathrm{t}_{\text {tabel }}$

Mengacu pada nilai thitung dan $\mathrm{t}_{\text {tabel }}$ maka pengambilan keputusan adalah terima $\mathrm{H}_{1}$ yaitu hasil belajar mahasiswa yang menggunakan media e-learning lebih tinggi daripada hasil belajar mahasiswa yang menggunakan media powerpoint.

\section{Kesimpulan}

Media pembelajaran e-learning pada mata kuliah sistem informasi manajemen layak digunakan untuk pembelajaran, hal ini karena semua indikator antara lain; validitas media mendapat skor rata-rata $85 \%$, kesesuaian media mendapat skor rata-rata 84\%, dan kemenarikan media mendapat skor rata-rata 
79,3\%. Sehingga dari hasil ini media pembelajaran e-learning layak untuk digunakan sebagai media pembelajaran.

Respon mahasiswa terhadap penggunaan media e-learning sesuai dengan pertanyaan antara lain; 1) e-learning menjadikan kegiatan pembelajaran lebih menyenangkan dikategorikan sangat baik dengan skor rata-rata 3,56,2) e-learning meningkatkan keaktifan mahasiswa dikategorikan baik dengan skor rata-rata 3,16, 3) e-learning meningkatkan minat mahasiswa dengan skor rata-rata 3,24, 4) e-learning hal yang baru dan sangat menarik dikategorikan sangat baik dengan skor rata-rata 3,40,5) e-learning membuat mahasiswa mudah memahami konsep yang komplek dan abstrak dikategorikan sangat baik dengan skor rata-rata 3,52,6) e-learning membuat mahasiswa lebih mudah menyelesaikan soal-soal dikategorikan sangat baik dengan skor rata-rata 3,40,7) e-learning meningkatkan daya serap atau retensi belajar dikategorikan sangat baik dengan skor rata-rata 3,36,8) e-learning cocok digunakan di Universitas dikategorikan sangat baik dengan skor rata-rata 3,48,9) e-learning cocok digunakan materi sistem informasi manajemen dikategorikan sangat baik dengan skor rata-rata $3,44,10) e$ learning sesuai dengan kurikulum yang digunakan di Universitas dikategorikan sangat baik dengan skor rata-rata 3,40.

Keterlaksanaan pembelajaran dengan menggunakan media pembelajaran e-learning dengan skor rata-rata 4 yang dikategorikan baik sehingga media pembelajaran e-learning dalam kegiatan belajar mengajar dapat terlaksana dengan baik.

Hasil belajar mahasiswa dengan menggunakan media e-learning mendapat nilai rata-rata hasil tes belajar untuk kelas eksperimen adalah 85,5\% dan untuk kelas kontrol adalah 79,46\%. Berdasarkan hasil uji t pada Tabel 4.12 diketahui bahwa hasil $t_{\text {hitung }}$ sebesar 3,747 sedangkan nilai tabel adalah 1,671. Mengacu pada hasil uji t maka diketahui maka $t_{\text {hitung }}>t_{\text {tabel }}$. Berdasarkan pada kriteria pengambilan keputusan hipotesis maka terima $\mathrm{H}_{1}$ yaitu hasil belajar mahasiswa yang menggunakan media $e$ learning lebih tinggi daripada hasil belajar mahasiswa yang menggunakan media powerpoint.

\section{Daftar Pustaka}

[1] Asyhar, Rayandra. 2012. Kreatif Mengembangkan Media Pembelajaran. Jakarta: Refesrensi

[2] Aunurrahman. 2011. Belajar dan Pembelajaran. Bandung: Penerbit CV. Alfabeta

[3] Daryanto, 2010. Media Pembelajaran, Peranannya Sangat Penting Dalamn Mencapai Tujuan Pembelajaran. Yogyakarta: Gava Media

[4] Riduwan. 2011. Belajar Mudah Penelitian untuk Guru-Karyawan dan Peneliti Pemula. Bandung: Alfabeta

[5] Sudjana, Nana. 2005. Metoda Statistika. Bandung : Tarsito

[6] Sugiyono. 2010. Metode Penelitian Kuantitatif Kualitatif dan R\&D. Bandung: Alfabeta 